\title{
Detecting the Planform Changes Due to the Seasonal Flow Fluctuation and 2012 Severe Flood in the Amazon River near Iquitos City, Peru Based on Remote Sensing Image Analysis
}

\author{
Karen Garcia Angulo ${ }^{1,2}$ and Kwan Tun Lee 2,3,* $^{\text {Kan }}$ \\ 1 Ludwig-Franzius-Institute for Hydraulic, Estuarine and Coastal Engineering, Leibniz University Hannover, \\ 30167 Hannover, Germany; garcia@lufi.uni-hannover.de \\ 2 Department of River and Harbor Engineering, National Taiwan Ocean University, Keelung 202, Taiwan \\ 3 Center of Excellence for Ocean Engineering, National Taiwan Ocean University, Keelung 202, Taiwan \\ * Correspondence: ktlee@ntou.edu.tw; Tel.: +886-2462-2192 (ext. 6121)
}

check for updates

Citation: Garcia Angulo, K.; Lee, K.T. Detecting the Planform Changes Due to the Seasonal Flow Fluctuation and 2012 Severe Flood in the Amazon River near Iquitos City, Peru Based on Remote Sensing Image Analysis. Water 2022, 14, 509. https://doi.org/ $10.3390 /$ w14030509

Academic Editors:

Helmut Habersack, Michael Tritthart, Martin Schletterer and Markus Eder

Received: 14 December 2021

Accepted: 2 February 2022

Published: 8 February 2022

Publisher's Note: MDPI stays neutral with regard to jurisdictional claims in published maps and institutional affiliations.

Copyright: (c) 2022 by the authors. Licensee MDPI, Basel, Switzerland. This article is an open access article distributed under the terms and conditions of the Creative Commons Attribution (CC BY) license (https:// creativecommons.org/licenses/by/ $4.0 /)$.

\begin{abstract}
The Upper Amazon River forms an anabranching planform, which has been found to have significant changes in migration rate and river morphology. Previous studies have elaborated long-term evolution of the anabranching systems; however, research on the influence of the water level on temporal changes in anabranching is absent. According to the theory of river hydraulics, fluvial scour usually occurs when the shear force possessed by the high flow exceeds the resistance of the streambank. In contrast, deposition occurs when the tractive force of the low flow is insufficient to overcome the forces of gravity and friction. This study investigated the Muyuy anabranching planform change of the Upper Peruvian Amazon River due to the seasonal flow fluctuations and a severe flood in 2012. The Muyuy anabranching area is located $20 \mathrm{~km}$ upstream of Iquitos City, Peru. Landsat images from the wet and dry seasons in 2008, 2009, 2012, and 2013 were collected. The images were classified into three land cover classes (water, bare soil, vegetation and others) based on NDVI analysis. Quantitative analysis of the erosion/deposition shows that deposition is more noticeable than erosion in the Muyuy anabranching area. Considerable deposition can be found on the island of the anabranching system, and the streambank erosion occurred in the outer (concave) side of the main channel. This phenomenon of river erosion and deposition consistently occurred in 2008 and 2009 because of the periodical variation among the wet and dry seasons. However, prominent erosion was observed in 2012 and it was recognized to be caused by the severe flood. Furthermore, the extensive island was formed in 2013, which means substantial depositions accumulated in the recession of the 2012 flood.
\end{abstract}

Keywords: river planform change; Amazon River; NDVI analysis; riparian erosion; deposition; Peru

\section{Introduction}

The river is a very complex and dynamic natural system. The primary function of the river is to deliver water, thereby transporting sediments and nutrients over long distances. As a river follows its course, critical morphological processes are triggered, such as the erosion of its bed and banks or the deposition of sediments, which form an alluvial sedimentation feature known as the floodplain. The floodplain is the land adjacent to the current channel water edge or land that is overbank and may taper away to the valley edge. Large river floodplains are extremely complex and varied [1], with multiple topographic features contributing to this complexity. The formation, preservation, structure, and topography of floodplains are still poorly understood, particularly for the larger rivers of the world.

The Amazon River is acknowledged as the largest river in the world in terms of the total annual discharge $\left(175,000 \mathrm{~m}^{3} \mathrm{~s}^{-1}\right)$ and drainage area $\left(6,915,000 \mathrm{~km}^{2}\right)$, and has a length of more than $6000 \mathrm{~km}$ extending from the Andean Region in Peru to the Atlantic 
Ocean in Brazil [2]. It is formed in the northeast of Peru by the confluence of two major rivers, the anabranching Marañon River and the meandering Ucayali River. These rivers are characterized by strong fluvial dynamics that greatly influence the abiotic and biotic environment and the transport of fluid and suspended sediments. Although extensive work has been dedicated to understanding this kind of river system, there are still open questions regarding their physically based formation processes and dynamics, especially for large system scales such as the lowland Amazonian rivers.

The erosion of the streambank and riparian areas depends on the flow discharge, channel cross-section, bank geometry, soil properties, and riparian vegetation. Fluvial scour occurs when the shear force produced by the flowing water exceeds the resistance of the streambank soil. Mass failures happen when the scouring on the streambank is continuous, which results in soil blocks sliding or toppling from the bank into the water. Although the geometry and soil properties of the streambank are the main factors that govern the failure extent of the streambank, vegetation on riparian areas can strengthen the bank's resistance to scouring. Wynn and Mostaghimi [3] evaluated the effects of root density and soil properties on the erodibility of streambanks through detailed field investigations. Chatterjee and Krishna [4] applied a USLE to assess the vulnerability of soil erosion, in which the factors contained in the USLE were estimated using DEM and satellite images. Daly et al. [5] applied a numerical model (BSTEM) to estimate streambank erosion and failure considering soil properties and root cohesion. Using a physically based watershed and a habitat suitability model, Botero-Acosta et al. [6] developed a methodology to identify the susceptible erosion areas along the streambank.

Remote sensing images have been applied to detect streambank erosion for many years. This approach can reduce the effort in field investigations and enable prediction of longterm trends in channel migration. In addition, the images are easy to obtain and analyze. Sale et al. [7] may be the pioneer of applying Landsat multi-spectral scanner (MSS) images to estimate the lateral meandering migration rates of rivers. Yang et al. [8] monitored the dynamics of the Yellow River Delta of China using MSS and TM images with GIS technology. Kummu et al. [9] detected the riverbank changes in the Vientiane-Nong Khai section of the Mekong River based on SPOT5 satellite images analysis. Hassan and Mahmud-ul-islam [10] analyzed bank erosion and bar deposition in the Chowhali Upazila River of Bangladesh based on the Landsat TM-5 and Landsat-8 imageries from 1989 and 2015. Most recently, high resolution KOMPSAT images were applied to observe the detailed migration rate of the tidal channel [11]. Numerous studies have been carried out on the morphology and planform migration of the Amazon River [12-16]. Rozo et al. [13,14] applied remote sensing techniques to analyze the planform change of the Colombian and Brazilian reaches of the Amazon River. In their studies, the comparison of the images was based on minimal water level variation while providing the widest temporal span. The discharge variation appeared to be the cause for deposition and erosion dynamics in the Colombian and Brazilian reaches of the Amazon River. Frias et al. [15] and Mendoza et al. [16] investigated the planform dynamics in the upper Peruvian Amazon River. Based on the satellite images and hydrodynamic model analyses, they described the transition of the planform from a single channel river to a multichannel system characterized by anabranching structures.

The unsteadiness of the flow in flood events has substantial effects on the flow field structure, which in turn affects the sediment movement, resulting in planform changes. Yen and Lee [17] investigated the velocity distribution, bedload transport, bed configuration, and bedform changes in a channel bend under unsteady-flow conditions. Based on flume test results, Lee et al. [18] reported that the bedload yield under unsteady-flow conditions was 1.6 times that obtained from steady-flow experiments, and the peak sediment transport rate in the unsteady flow was 1.4 times that observed in the equivalent steadyflow experiments. Numerical simulation showed that considerable erosion occurs in high flow floods. Flood propagation is accelerated after incorporating sediment transport [19]. A complete review was provided by Karimaee Tabarestani and Zarrati [20]; they concluded that the sediment transport rate in unsteady flow is usually higher than that in steady-flow 
conditions. The larger the unsteadiness, the bigger the difference. Hence, it is of interest to know about the morphology changes in the anabranching planform during a severe flood.

There are three anabranching structures in the upper Peruvian Amazon River: the Iquitos area, the Muyuy area, and the Triple boundary area (the boundary between Brazil, Colombia, and Peru). Although Mendoza et al. [16] investigated Iquitos anabranching structures, Frias et al. [15] studied the two latter structures and focused on the relationship between the sinuosity of the main channels and its effects on the dynamics of the secondary channel of the anabranching structures. They described the Muyuy anabranching area as a site with a medium to high sinuosity and the Triple boundary area as a site with a low sinuosity. Mendoza et al. [16] found an additional interesting channel behavior for the Iquitos anabranching structure. The channels migrate at different rates, where processes of narrowing and widening take place and new channels form or collide. All the researchers mentioned above focused on determining the planform evolution by performing a temporal analysis based on satellite images and field measurements. However, none addressed temporal changes between individual seasons. Investigating the seasonal variation in the channel planform change would be meaningful. The two primary purposes of this study were to evaluate the seasonal variation in the channel's planform changes during the years 2008 and 2013, and to investigate the impact of the 2012 severe flood on this anabranching structure.

\section{The Upper Peruvian Amazonian Rivers}

The Peruvian Amazon is considered one of the most biodiverse regions in the world, with a great number of endemic species (e.g., reptiles, amphibians, trees, primates, and birds) of which only a fraction (2-3\%) are even known to date. Puhakka et al. [21] stated that biodiversity is based on its relationship with river dynamics. The seasonal flow fluctuation in the Upper Peruvian Amazon River generates significant alterations in water surface elevation, river floods, riverbank, navigation erosion, and aquatic ecosystems; in addition, in the long term, it changes the river planform and altimetry patterns [22]. The morphology of the Amazon in the Upper Peruvian reach is very dynamic, with one of the biggest migration rates in the entire course of the Amazon River.

The river patterns found in the Peruvian Amazon River range from meandering rivers (e.g., Ucayali, Nanay, Yavari) to the well-matured anabranching type (e.g., Marañon, Amazonas). Abad et al. [23] described the differences and similarities of these river types. The meandering and anabranching structures have clearly different planform dynamics [24]. Meandering rivers result from their dynamic equilibrium conditions by generating meander trains under erosive and depositional processes. This structure has a single channel with lateral migration because the velocity is high at the outer bank [25,26]. Meandering behaviors were found in the main and secondary channels of the anabranching structures $[13,27]$. The anabranching structure shows the development of midchannel bars and island formations. Furthermore, the formation of islands and channel cuts was identified as the most significant influence of anastomose structures in this region, contrary to avulsion processes $[13,15]$. Anabranching structures ranging from low sinuosity to medium and high sinuosity can be found in the upper Peruvian Amazon River. Three anabranching structures have been studied in the upper Peruvian Amazon River [15,16]: the Muyuy area, the Iquitos area, and the Triple boundary area, representing the tri-border area between Brazil, Colombia, and Peru. As only limited research has been carried out so far on the hydrodynamics of these structures, the Muyuy anabranching structure was chosen as the study area to gain a deeper insight into the hydrodynamic processes in the Upper Peruvian Amazon River.

\section{Study Area}

\subsection{Description of the Muyuy Anabranching Structure}

As shown in Figure 1, the Muyuy anabranching structure is located in Peru, $20 \mathrm{~km}$ upstream from the City of Iquitos, the capital city of the Department of Loreto in the 
Peruvian Amazonia. The total study area comprises $552.06 \mathrm{~km}^{2}$ within the Maynas Province, Loreto Region, and is bordered by the Tamshiyacu Community on the east upstream side and the Cantagallo Community on the west downstream side.

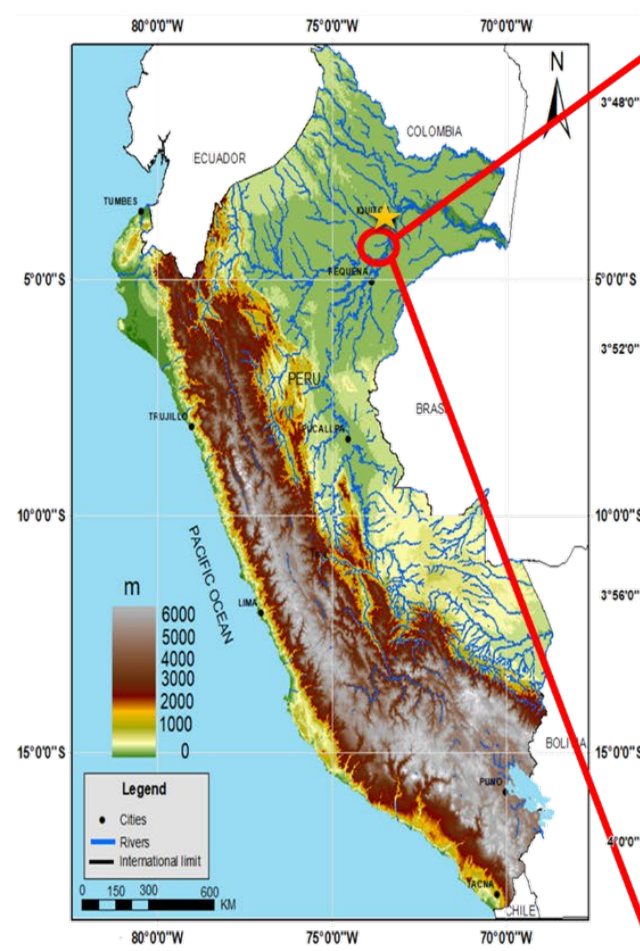

(a)

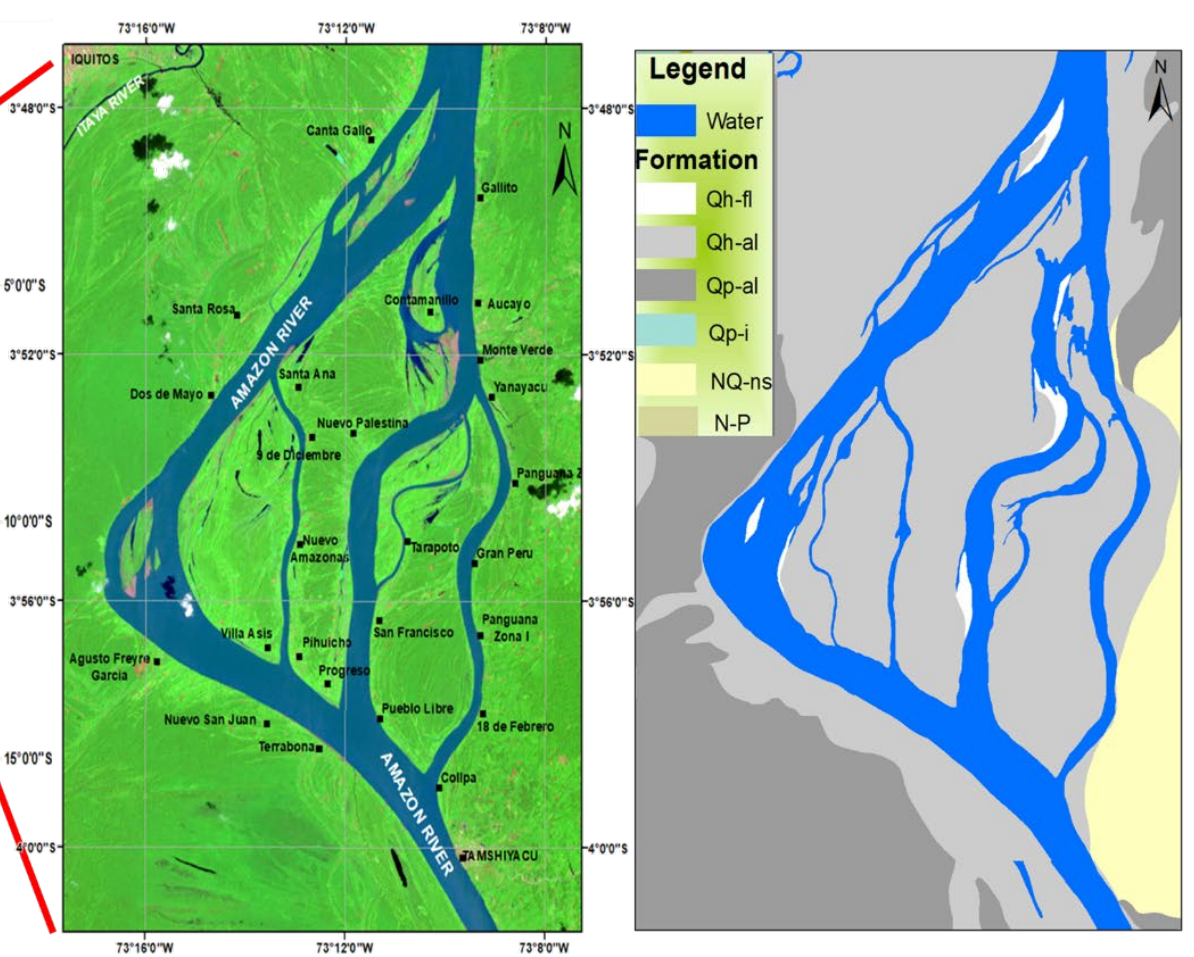

(b)

(c)

Figure 1. (a) Hypsometric map of Peru that shows the location of the study area in the upper Peruvian Amazon River in Peru (Muyuy anabranching structure). The yellow star represents the Iquitos gauging station. (b) The Muyuy structure (flow goes in the northern direction towards Brazil) with upstream village Tamshiyacu and downstream Canta Gallo. The 2009 satellite image was obtained from USGS. (c) The geology of the study area, Qh-fl: fluvial deposits from the Holocene period; Qh-al: alluvial deposits from the Holocene period; Qp-al: alluvial deposits from the Pleistocene period, Qp-i: Iquitos formation from the Pleistocene period, NQ-ns: Nauta formation superior from the Neogene period; N-P: Pebas formation from the Neogene period.

The valley elevation of the study area is less than $120 \mathrm{~m}$, and the width of the multichannel floodplain ranges from 23 to $24 \mathrm{~km}$; the floodplain is known for its exceptionally high rate of erosion and sedimentation $[12,15,16,28]$. Although the principal channel runs on the western side, next to the Augusto Freyre community, the secondary channels flow through the valley's eastern side. Additionally, the channel migration areas can be clearly defined by two geologic formations at the valley edges: the Pebas formation on the eastern edge and the Iquitos formation on the western edge [15]. Although the mean annual discharge through this reach amounts to $30,700 \mathrm{~m}^{3} / \mathrm{s}$, the discharge can vary from $10,000 \mathrm{~m}^{3} / \mathrm{s}$ during the dry season to $55,000 \mathrm{~m}^{3} / \mathrm{s}$ during the wet season [15]. According to Armijos et al. [29], the river flow transports a total suspended sediment yield of $10 \times 10^{6} \mathrm{t} \mathrm{month}^{-1}$ in the dry season and $78 \times 10^{6} \mathrm{t} \mathrm{month}^{-1}$ in the wet season.

Pinedo-Vásquez [30] stated that the total land area increases by about $30 \%$ when the river water levels approach their lowest annual level. In contrast, almost all land is flooded when water levels reach the peak. As a result, the Muyuy anabranching consists of various environments subject to flooding, which varies in both intensity and rate. It is also characterized by extensive bank erosion and deposition due to lateral migration and other processes of strong fluvial dynamics due to its location on a highly dynamic floodplain. 


\subsection{Geologic Background}

The Amazon basin is surrounded on the west by the Andes, on the north by the Guiana Shield, and on the southeast by the Brazilian Shield [27,31]. Räsänen et al. [32] derived a map containing the description of the Muyuy anabranching region in geological units showing (1) Pebas formation, (2) Nauta unit, (4) Iquitos unit, (5) fluvial terraces, and (6) alluvial deposits. These geological structures formed within three time periods: (1) Lacustrine, 18-11 Ma ago, when Pebas lake was formed in the occidental Amazonia, followed by possible flooding of the Colombian plains, where marine conditions would have prevailed. (2) Estuarine, 11-8 Ma ago; in this period the tectonic activity of the Andes increased due to the interruption of the northern sea, and therefore contributed to the deposition of Andean fluvial material. (3) Fluvial, from $8 \mathrm{Ma}$ until now, describing the present course taken by the Amazon River and the great influence that tectonic activity had on the development of terraces and the alluvial floodplains. A similar geological map was lately updated by the Geological Service of Peru in 2016, as shown in Figure 1c.

In the geological map presented in Figure 1c, it can be seen that the extension of the anabranching structure is limited by the Nauta unit on the eastern side (unit resistant to fluvial erosion), which consists of layers of clay bed, including sand and lignite beds [33]. On the western side, the Muyuy anabranching structure is framed by alluvial floodplains denoted as alluvial deposits, formed by the migrating channels characterized with scroll bars [32]. Mendoza et al. [16] reported that the Amazon River has a high rate of planform migration within the alluvial deposits, which belong to the Holocene epoch and are indicated by the scroll bars.

\subsection{Water Level Variations of the Amazon River}

According to the data provided by the Service of Hydrography and Navigation of the Amazon, historical water levels of the Amazon River demonstrate the variability of the water level at the Iquitos station (downstream Muyuy anabranching structure). Figure 2A shows the development of the minimum (red), mean (green), and maximum (blue) water levels at the Iquitos gauging station from 1968 to 2018. Figure 2A demonstrates that the minimum water levels during the dry seasons have steadily decreased in recent years, whereas the maximum and average water levels have remained at the same level. Furthermore, two historical outliers follow each other closely: the drought period in 2010, with the lowest minimum water level ever recorded, followed shortly by the flood in 2012, with a historical maximum water level of 118.97 ma.s.l., as indicated by the red circle.

Four states can characterize the flooding dynamic based on the records in the Iquitos ganging station. As shown in Figure 2B, the rising state indicates the period from November to February, where the water level increases at a rate greater than $3.6 \mathrm{~cm}$ per day. In the high flow period (from March to May), the increasing rate of the water level is about $3.2 \mathrm{~cm}$ per day, and the falling rate is about $3.9 \mathrm{~cm}$ per day. Finally, the low flow state is from August to October, when the water level reaches minimum levels and undergoes few variations.

According to Marengo and Espinoza [34], the flooding of 2012 was higher than that of the previous record extreme in 2009, and the drought in 2010 was the most severe in the past 40 years. The increase in these extreme events in the last decade is alarming, as it may be an indicator that these events are becoming more frequent due to anthropogenic climate change. 

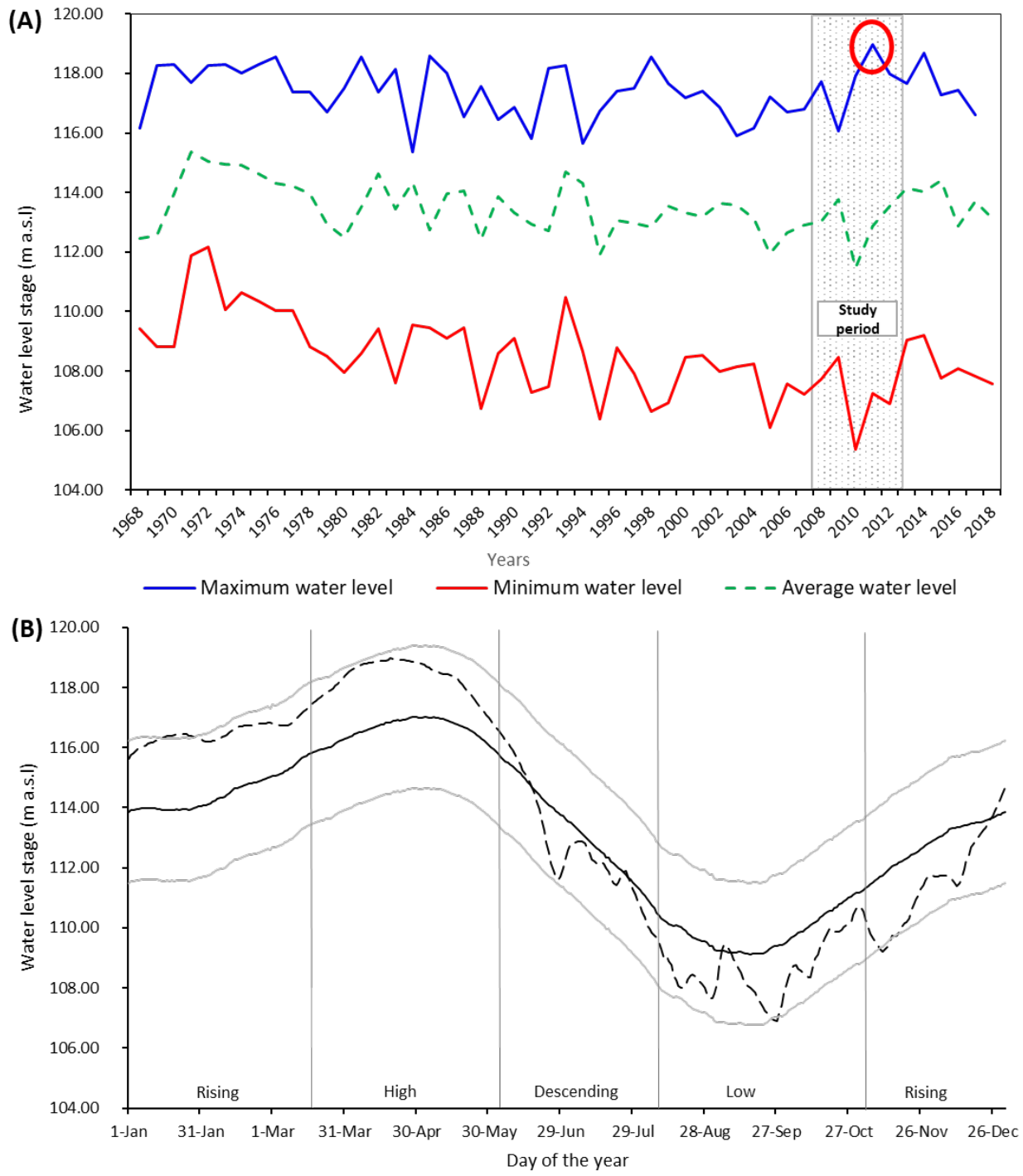

Figure 2. (A) The water surface elevation was measured for 50 years from 1968 to 2018 at the Iquitos gauging station. The maximum water level occurred in April 2012, of 118.97 ma.s.l., and the minimum was in October 2010, of 105.26 ma.s.l. (B) The dotted line illustrates the abnormally high-water levels in the 2012 flood. The solid line is the mean water elevation, and the gray lines show the $95 \%$ confidence interval of the water elevation based on the records measured in 1968-2018. The dashed line indicates the abnormally high water levels in the 2012 flood. Four stages are used to characterize the hydrograph, namely, the rising stage, high stage, descending stage, and low stage.

\subsection{Dynamics of Muyuy Anabranching Structure}

The dynamics of the Muyuy anabranching structure have been analyzed through temporal analysis based on historical satellite images in previous studies. Kalliola et al. [12] focused on analyzing the change between 1979 and 1983, and Frias et al. [15] investigated the changes from 1985 to 2014. In the mentioned studies, field data (bathymetry, velocity field, and water surface elevation) were collected for processing and used in a two-dimensional hydrodynamic model to better understand the study area. They found that the main channel of this structure rapidly migrates at a rate of $300-400 \mathrm{~m} / \mathrm{yr}$. They characterized this anabranching system as the main channel, having from medium to high sinuosity. The principal channel of this structure is highly sensitive to the maximum channel migration, and is located in the younger depositional formations (as opposed to the bordering, non-flooded terra firm deposits). Additionally, it is located away from the valley edge, whereas the local geology suppresses the planform dynamics of the secondary 
channels adjacent to the valley edge. As a result of collisions with other secondary channels, the secondary channels' planforms changed significantly. These processes are especially important for investigating the evolution of anabranching structures in larger rivers.

In this anabranching structure, the sand bars developed into an island, and the secondary channels are bed-elevated compared to the principal channel. As a result, the principal channel is $75 \%$ wider than the secondary channels. The discharge, however, is not distributed proportionally between channels. The bifurcation angle can influence the flow process, the position of the inlet, and the planform shape of the secondary channels.

\section{Methodology}

Figure 3 shows the five steps conducted in this study. Details of the steps are explained in the following.

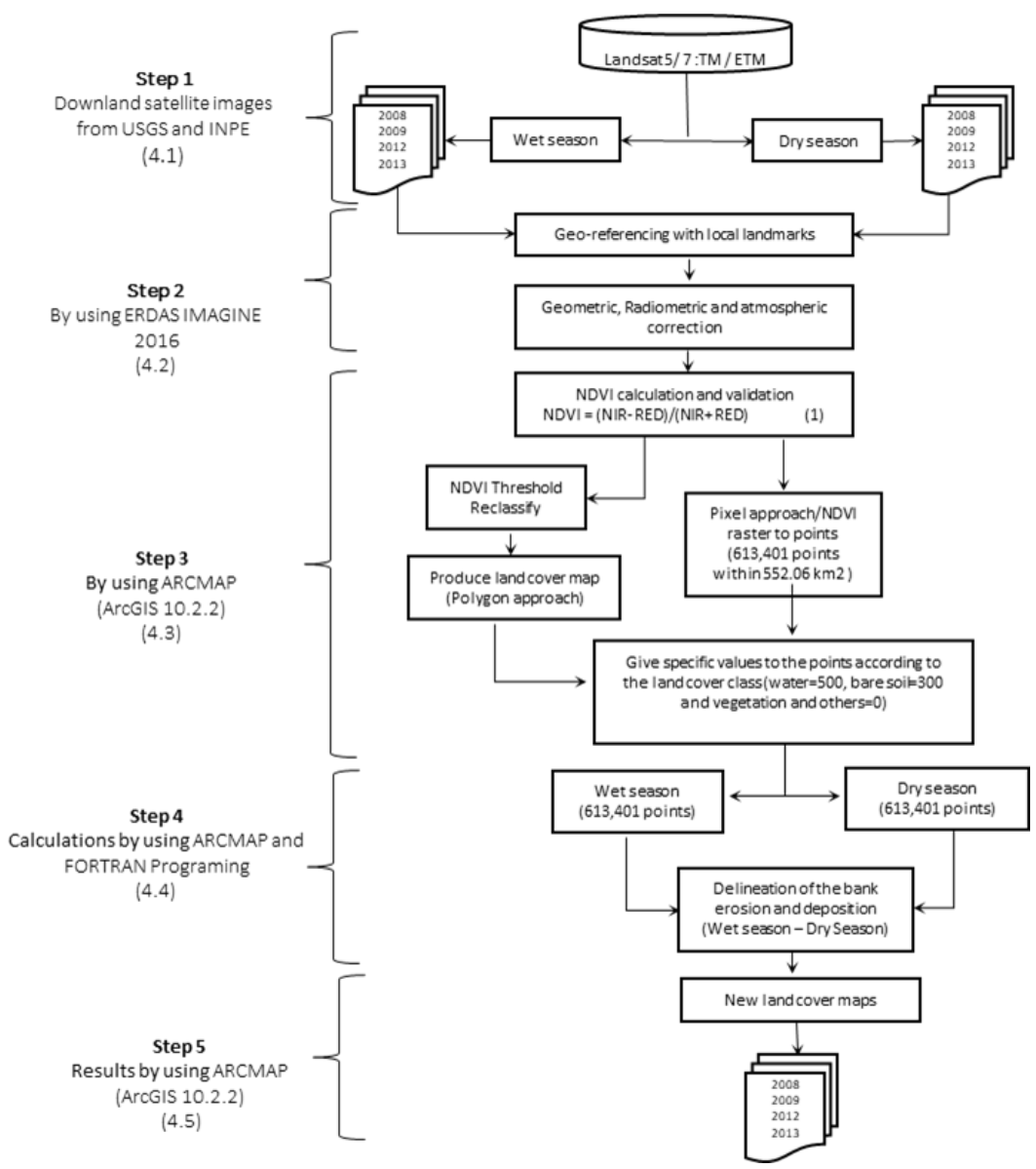

Figure 3. Flowchart of the methodology.

\subsection{Planform Change Detection Based on Image Classification (Step 1)}

Landsat 5 and 7 images from 2008, 2009, 2012, and 2013 were collected; these images were used to investigate the channel planform changes due to the seasonal flow fluctuations and the 2012 flood. The Landsat image data and the maximum annual water level at the Iquitos gauging station are summarized in Table 1 . These satellite images were obtained from the National Institute for Space Research and the United States of Geological Survey (USGS) website. Individual images within the period of January to March (the wet season) and in September (the dry season) were used to visualize the overall scenery of the study area. Clouds have been found in previous studies to reduce land cover classification accuracy because they can significantly affect the accuracy of land cover classification $[35,36]$. As suggested by Chavez [37] and Milanović et al. [38], the cloud cover of images used for 
analysis was less than 20\%. Seven bands from Landsat 5 and eight bands from Landsat 7 were considered for image classification. The aerial photographs obtained from the Service of Hydrography and Navigation of the Amazon (SHNA), as shown in Figure 4, exemplarily illustrate the water level variation between the wet and dry seasons near the city of Iquitos.

Table 1. LANDSAT data and the annual maximum water level during the observed period.

\begin{tabular}{|c|c|c|c|c|c|}
\hline Mission & Sensor & Date & Bands & Season & $\begin{array}{l}\text { Annual Maximum Water Level } \\
\text { (Meters above Sea Level; m.a.s.l) }\end{array}$ \\
\hline L-7 & ETM+ & 11 January 2008 & B3,B4 & Wet & \multirow{2}{*}{116.80} \\
\hline L-5 & $\mathrm{TM}+$ & 15 September 2008 & $\mathrm{~B} 3, \mathrm{~B} 4$ & Dry & \\
\hline L-5 & $\mathrm{TM}+$ & 26 March 2009 & B3,B4 & Wet & \multirow{2}{*}{117.73} \\
\hline L-5 & $\mathrm{TM}+$ & 2 September 2009 & $\mathrm{~B} 3, \mathrm{~B} 4$ & Dry & \\
\hline L-7 & ETM+ & 26 March 2012 & B3,B4 & Wet & \multirow{2}{*}{118.97} \\
\hline L-7 & ETM+ & 18 September2012 & B3,B4 & Dry & \\
\hline L-7 & ETM+ & 25 February2013 & B3,B4 & Wet & \multirow{2}{*}{117.99} \\
\hline $\mathrm{L}-7$ & ETM+ & 21 September2013 & B3,B4 & Dry & \\
\hline
\end{tabular}

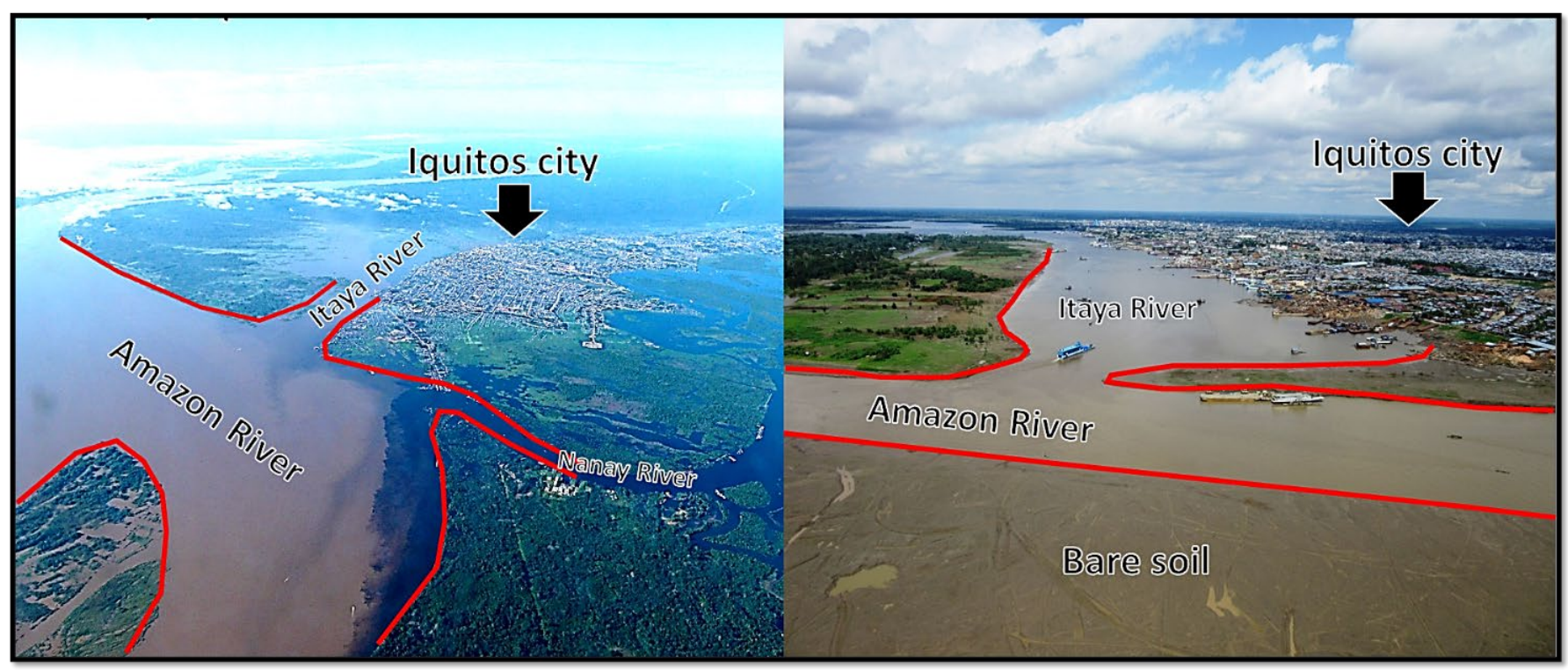

(a)

(b)

Figure 4. Aerial photos taken in the (a) wet season and (b) dry season in the Amazon reach (from the Service of Hydrography and Navigation of the Amazon; SHNA). The red line shows the channel of the river. The channel is wide in the wet season and narrow in the dry season because of the water level and the sediment deposition as bare soil.

\subsection{Images Processing (Step 2)}

Satellite images are geometrically distorted because of the Earth rotation effect, changes in the instant field of view and altitude, and platform tilt and rotation. Thus, it is necessary to pre-process the remote sensing images and remove geometric distortion. In this study, the satellite images were processed in the ERDAS Imagine 2016 software to correct the bands for radiometric and atmospheric distortions, and co-register and geo-reference them into the same geographic system [39]. Ground control points (GCPs) are used to rectify the geometric distortion and appropriate mathematical models [40]. A GCP is a location or geographical landmark on the Earth's surface that can be accurately identified in the imagery. Image-to-image registration is a method of geometric correction. This is a critical task in change detection, particularly for image differencing. The GCPs were obtained from the Service of Hydrography and Navigation of the Amazon (see Table 2). The Landsat 
images used in this study were downloaded from USGS and INPE. These images were projected, corrected, and adjusted geometrically by USGS using the UTM projection method by the subset tool in ERDAS to increase accuracy and precision. The bands were examined for dark objects, i.e., pixels with minimal brightness values in the Near Infrared (NIR) and Red (RED) bands [41].

Table 2. Geographical landmarks.

\begin{tabular}{|c|c|c|c|c|c|}
\hline $\mathbf{N}^{\circ}$ & Station & $\begin{array}{c}\text { UTM } \\
\text { Coordinates }\end{array}$ & $\begin{array}{l}\text { Geographical } \\
\text { Coordinates }\end{array}$ & $\begin{array}{c}\text { Geoidal } \\
\text { Elevation }\end{array}$ & Signal \\
\hline 1 & Tamshiyacu & $\begin{array}{c}9557248.285 \mathrm{~N} \\
704161.971 \mathrm{E}\end{array}$ & $\begin{array}{c}4^{\circ} 00^{\prime} 12.8816^{\prime \prime} \mathrm{S} \\
73^{\circ} 09^{\prime} 39.9759^{\prime \prime} \mathrm{W}\end{array}$ & 98.914 & $\begin{array}{c}\text { Geographical } \\
\text { landmark }\end{array}$ \\
\hline 2 & Iquitos & $\begin{array}{c}9586988.403 \mathrm{~N} \\
695426.947 \mathrm{E}\end{array}$ & $\begin{array}{c}3^{\circ} 44^{\prime} 05.3642^{\prime \prime} \mathrm{S} \\
73^{\circ} 14^{\prime} 25.1186^{\prime \prime} \mathrm{W}\end{array}$ & 90.063 & $\begin{array}{c}\text { Geographical } \\
\text { landmark }\end{array}$ \\
\hline
\end{tabular}

\subsection{NDVI Calculation and Validation (Step 3)}

The Normalized Difference Vegetation Index (NDVI) is the ratio of near infrared (NIR) and red (RED) band regions that correspond to canopy vigor and cover. NDVI is a reflectance measurement that can provide meaningful information on vegetation growth and biomass [42]. Plants and their roots impact the physical characteristics of soil, such as infiltration capacity, cumulative stability, moisture levels, and shear strength, all of which play a role in soil conservation [43]. Furthermore, vegetation and their roots reduce runoff and soil erosion in dry and wet seasons [44-46]. The plant root system plays a critical role in gully and streambank stabilization by improving soil shear strength $[47,48]$.

Eight satellite images from 2008, 2009, 2012, and 2013 were evaluated by the NDVI analysis using a map algebra tool (raster calculator) in the spatial analysis of ArcMap (ArcGIS 10.2.2), as defined in Step 2 shown in Figure 3. Some surfaces, particularly healthy plant leaves, strongly reflect the electromagnetic spectrum in NIR. By comparison, red light is absorbed almost entirely by leaf chlorophyll for photosynthesis. Many remotely sensed vegetation indices use this concept but include some modification as an attempt to correct confounding factors present in the atmosphere and soil due to temporal and spatial heterogeneity [39]. The NDVI value can be expressed as:

$$
\mathrm{NDVI}=(\mathrm{NIR}-\mathrm{RED}) /(\mathrm{NIR}+\mathrm{RED})
$$

The NDVI scale ranges from -1 to +1 , with higher values representing more robust and healthier vegetation. The very low values ( 0.1 and lower) denote rock, sand, or barren snow places. Moderate values (0.2 to 0.3$)$ reflect shrub and grassland, whereas high values (0.6 to 0.8 ) represent temperate and tropical rainforests [49].

The NDVI calculation for the eight satellite images from the four studied years resulted in different wet/dry season threshold values. For the wet season, the threshold between water and bare soil was -0.1 , the threshold between bare soil and grassland was 0.09, and the threshold between grassland and higher vegetation was 0.4 . For the dry season, the calculated threshold values were -1 to -0.25 for water, -0.25 to 0.20 for bare soil, 0.20 to 0.5 for grassland, and 0.5 to +1 for healthy and higher vegetation. Although it is difficult to discern differences in the vegetation type using the NDVI due to the very lush tropical rainforest vegetation in this area, the NDVI analysis allows a clear delamination between vegetation, bare soil, and water in both seasons. The results from the calculation varied because NDVI is susceptible to the soil background effects, observation and illumination geometry, and atmospheric effects [50-52]. For inundated surface features, the determination of NDVI threshold values is critical because flooding conditions can vary significantly from place to place. According to Sanyal and Lu [53], the main challenge in determining an adequate threshold value is derived from two factors. First, because of the large quantity of sediment in the flooded water, the albedo of water bodies increases significantly. Second, the albedo of bare soil decreases considerably during the monsoon 
season due to its high moisture content. These two elements work together to lessen the NDVI difference between inundated and dry areas. As a result, a simple strategy of using simple NDVI values may not be universally helpful in identifying submerged areas. It is important to apply an additional supervised classification to the results.

A supervised maximum likelihood classification method was used to generate objective land cover maps of the wet and dry seasons in the study area. An accuracy assessment was also used to examine the classification results. The accuracy of numerical land cover classifications can be quantified by developing and inputting a classification error matrix. The error matrix compares information from a categorized picture or land cover map to known (actual) reference locations for a set of sample points. Google Earth pictures, true and false color photographs, and prior information were used as references. The accuracy assessment of land cover maps extracted from Landsat data involved the generation of 500 random references (fact points) for each land cover map to estimate the potential for error in each map. Four scales were tested, namely, global accuracy, kappa coefficient, product, and user accuracy [54].

\subsection{Land Cover Classification Based on NDVI (Step 4)}

The raster remote sensing images were classified into three land cover classes using the spatial analysis tool/reclassification option based on the NDVI calculation. The three classes were defined as: (1) water, (2) bare soil, and (3) vegetation and others, following the procedure provided by Sharma et al. [55]. Previous research regarding river channels has used this classification to determine the extent of river channels regardless of river level [56-64]. However, seasonal vegetation cover and hanging vegetation changes may confuse the channel bank delineation $[59,61]$. In fact, it is expected that a loosening bank section in the channel will not support vegetation growth because it is frequently exposed to overtopping and sediment transport. After classifying the image pixels into different land cover classes, a polygon-based approach was used to assign the defined land cover classes into the groups categorized with specific values [65]. The three classes are water in blue, bare soil in brown, and vegetation and others in green. Figure 5 shows the NDVI raster maps in 2008, 2009, 2012, and 2013. The A-Series images (A-1 to A-4) represent the wet season (January-March), and the B-Series images (B-1 to B-4) represent the dry season (September). The images were converted into independent pixels by the conversion tool in ArcMap. The total number of pixels obtained was 613,401 within the $552.06 \mathrm{~km}^{2}$ of the study area. The pixels were georeferenced with their $X$ and $Y$ values (using the geometry calculator from the attribute table in ArcMap).

Concerning the land cover classes, remarkable differences between the wet and dry seasons can be observed in the Muyuy anabranching structure. As expected, the proportion of the bare soil is considerably higher in the dry season than that in the wet season for all the studied years. This is particularly pronounced for the island in the main channel and the area where the main channel merges again with the secondary channels. In addition, some smaller sidearms, for example, the one in the upper eastern area, are completely dry during the dry season. Furthermore, a historical flood occurred during the dry season in 2012, and shows the largest bare soil areas. Overall, there was a considerable variation in the bare soil during the dry season in the four studied years. For example, in the dry season of 2012 (Figure 5B-3), the image shows an area of bare soil of $24.36 \mathrm{~km}^{2}$, which is significantly larger than those in other years. On the other hand, in the dry season of 2008 (Figure 5B-1), the vegetation and others areas reached the most considerable portion of $461.53 \mathrm{~km}^{2}$. Moreover, it can be observed that in the wet season of 2008 (Figure $5 \mathrm{~A}-1$ ), the main channel exhibits a small island of $0.90 \mathrm{~km}^{2}$ and four secondary channels; whereas, in the wet season of 2013 (Figure 5A-4), the main channel displays several small islands which vary in size from 0.10 to $0.40 \mathrm{~km}^{2}$. 


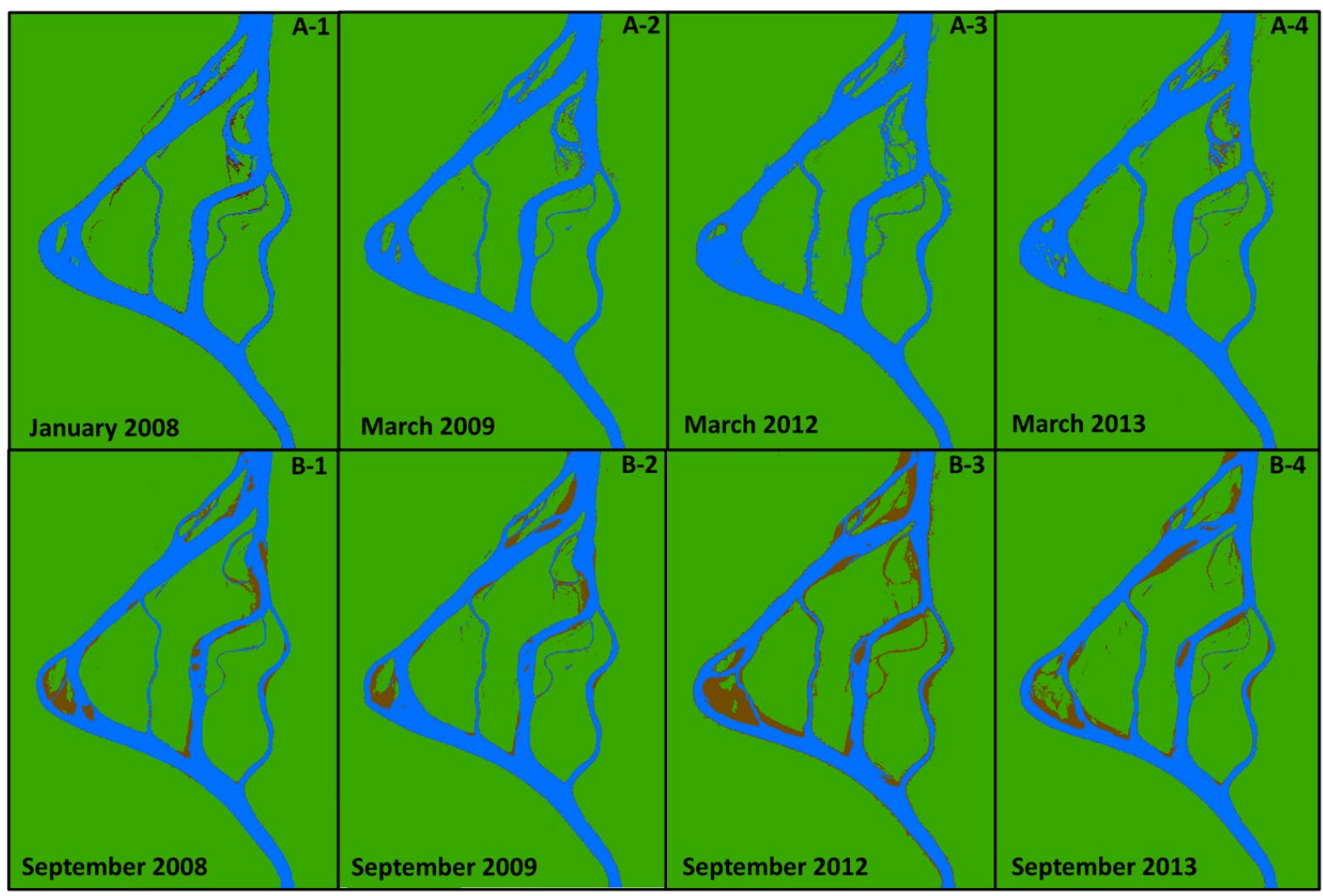

Water Bare soil

Vegetation and others

Figure 5. Land cover classification of the Muyuy anabranching structure in the upper Peruvian Amazon (water: blue, brown: bare soil, and green: vegetation and others) in 2008-2013. Series images (A-1-A-4) represent the wet season (January-March), and series images: (B-1-B-4) represent the dry season (September).

\subsection{Delineation of Bank Erosion and Deposition (Step 5)}

Delineation of bank erosion and deposition requires two georeferenced land cover maps of the study area from two successive dates (wet and dry seasons) with pixels projected onto a uniform grid of identical dimensions and resolutions. Previous studies have used two classes (binarymasks) to delineate the planform change [57,62,66-78]. As shown in Figure 6, this study used the land cover maps in the two successive seasons (wet and dry) with three classes (water, bare soil, vegetation and others). Hence, the bank erosion and deposition can be detected by investigating the change in the land cover classification using the two images. Figure $6 \mathrm{a}, \mathrm{b}$ shows the land cover distributions in the wet and dry seasons of 2012, respectively. As shown in Figure 6c, the black color represents bank erosion, indicating the land cover changing from vegetation and others to water. The red color denotes deposition, which means the land cover changes from water to vegetation and others. As expected, according to the sedimentation theory, the deposition occurred along the inner bank of the river bend, and erosion was found along the outer bank. 

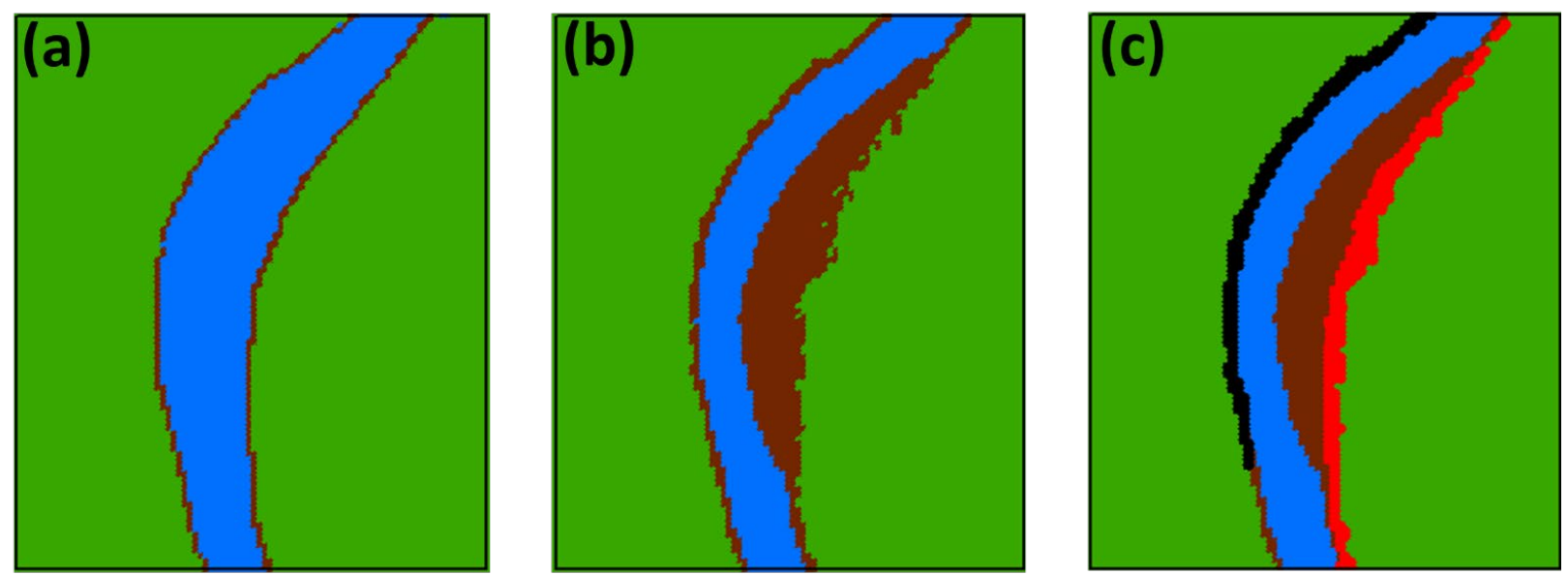

Water Bare soil Vegetation and others

Bank erosion

Deposition

Figure 6. Results of the land cover analysis in the wet season (a) and dry season (b). In (c), the black color represents bank erosion, indicating the land cover changing from vegetation and others to water. The red color denotes deposition, which means the land cover changes from water to vegetation and others.

\section{Results and Discussion}

\subsection{Seasonal Planform Change}

As shown in Figure 2B, the seasonal flow fluctuation is explicit in the upper Amazon River. This section investigates the seasonal planform change of the Muyuy anabranching area in the wet and dry seasons using the Landsat images taken in 2008, 2009, 2012, and 2013. According to the historical flow data of the Iquitos gauging station, the peak flows in the wet season usually occur between March and May. However, significant cloud coverage is usually found in the images taken from March to May, which prevented conducting the land cover analysis. Hence, images taken from January to March were used instead in this study.

Table 3 shows the variation in the three land cover classes in the wet/dry seasons. For the wet season, the variation in the water area was from $83.32 \mathrm{~km}^{2}$ in 2008 to $89.81 \mathrm{~km}^{2}$ in 2012 , which corresponds to a change of $1.17 \%$ with respect to the total area of $552.06 \mathrm{~km}^{2}$. The change in the bare soil was from $4.67 \mathrm{~km}^{2}$ in 2009 to $7.98 \mathrm{~km}^{2}$ in 2013, depicting a slight change of $0.60 \%$. For the area of vegetation and others, the maximum change was $6.51 \mathrm{~km}^{2}$, corresponding to $1.18 \%$ of the total area. As expected, the water area during the wet seasons was significantly larger than that in the dry seasons, whereas the bare soil in the wet season was much less than that in the dry season.

Table 3. Variation in land cover in the wet/dry seasons in the Muyuy anabranching area.

\begin{tabular}{|c|c|c|c|}
\hline \multirow[b]{2}{*}{ Year } & \multicolumn{3}{|c|}{ Areas in the Wet/Dry Seasons } \\
\hline & $\begin{array}{l}\text { Water } \\
\left(\mathbf{k m}^{2}\right)\end{array}$ & $\begin{array}{c}\text { Bare Soil } \\
\left(\mathrm{km}^{2}\right)\end{array}$ & Vegetation and Others $\left(\mathrm{km}^{2}\right)$ \\
\hline 2008 & $83.32 / 69.54$ & $6.20 / 12.07$ & $462.54 / 470.46$ \\
\hline 2009 & $84.52 / 73.42$ & $4.67 / 12.31$ & $462.87 / 466.33$ \\
\hline 2012 & $89.81 / 62.11$ & $5.65 / 31.00$ & $456.60 / 458.96$ \\
\hline 2013 & $87.72 / 64.37$ & $7.98 / 18.04$ & $456.36 / 469.65$ \\
\hline
\end{tabular}

Note: The total area in the Muyuy anabranching region is $552.06 \mathrm{~km}^{2}$.

For the dry season, the water area varied by $2.05 \%$, from $62.11 \mathrm{~km}^{2}$ in 2012 to $73.42 \mathrm{~km}^{2}$ in 2009. Although the water area is comparatively small during the dry season, the variation between years is more prominent during the dry season than that in the wet season. The same result can be found for the bare soil area, which changes considerably by $3.41 \%$ 
during the dry seasons. The water area in the wet season of 2012 was found to the largest in the studied four years because of the 2012 severe flood. Moreover, the bare soil in the dry season after the 2012 flood was significantly larger than in other years. This is because the substantial deposition accumulated during the recession of the severe flood.

Figure 7 demonstrates the spatial distribution of bank erosion and deposition based on the images taken in the wet/dry seasons of the four-year of study period. In this figure, black indicates where the bank erosion occurred, and red depicts the occurrence of deposition. From 2008 (Figure 7a) to 2009 (Figure 7b), only minor changes can be observed in the bank erosion and deposition distribution. In both years, deposition around the small islands in the main channel took place, and a small amount of bank erosion occurred at the main channel's outer bank (west side). Some bank erosion can also be found in the northern part of the study area, where the main and secondary channels merge again.

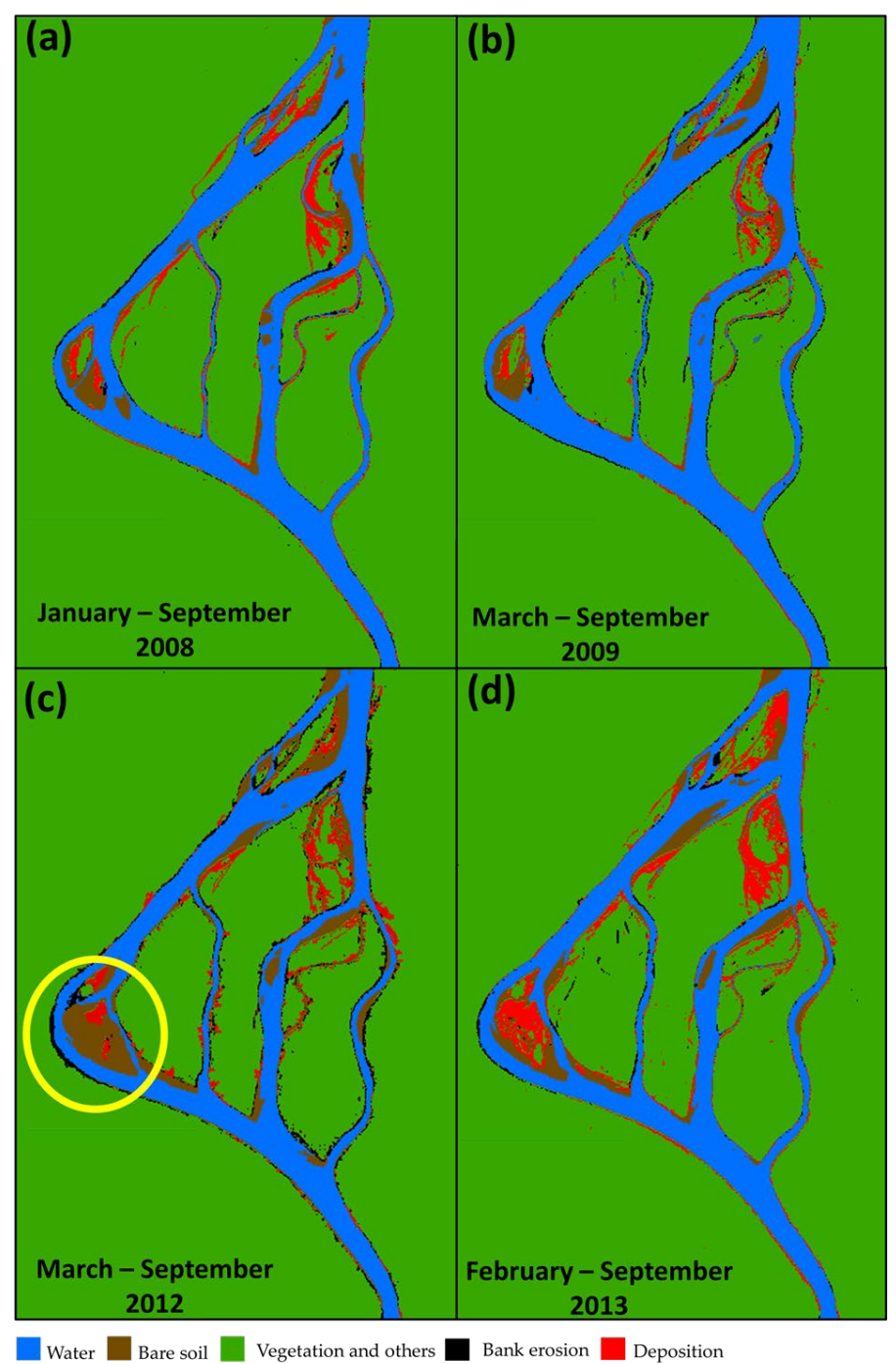

Figure 7. Figure (a) 2008, (b) 2009, (c) 2012 and (d) 2013 represent the bank erosion and deposition between the wet and dry seasons in the Muyuy anabranching area. In this map, (1) black color: bank erosion areas, (2) blue color: water areas, (3) brown color: bare soil areas, (4) red color: deposition occurred, and (5) green color: vegetation and others. The bank erosion and deposition were relatively consistent in 2008 and 2009. The yellow circle shows the high erosion area in the flooding year of 2012.

\subsection{Influence of the 2012 Severe Flood}

As shown in Figure 7c, the land cover changed considerably due to the 2012 severe flood. As a result, the amount of bank erosion increased significantly, especially at the outer bank of the main channel, as highlighted by the yellow circle. In contrast, the distribution 
of land areas in 2013 (Figure 7d) shows a considerable erosion around the islands in the main channel, at the inner side of the main channel, and in the secondary channels. These demonstrate a significant impact of the 2012 severe flood on the planform in the Muyuy anabranching area.

The small island in the main channel has an important effect on the channel dynamics. Figure 8 provides a more detailed investigation of the bank erosion and deposition distribution around the island throughout the years. In 2012, the main channel showed an active bank erosion on the outer bank. A large amount of bare soil can be observed around the small island. Although the island in the main channel is formed and shaped by the high flow period every year, it did not change significantly during 2008 and 2009 in terms of bank erosion and deposition. However, in 2013 the island was formed explicitly in places previously defined as bare soil in 2012, so that the bare soil from 2012 was changed to deposition in 2013.

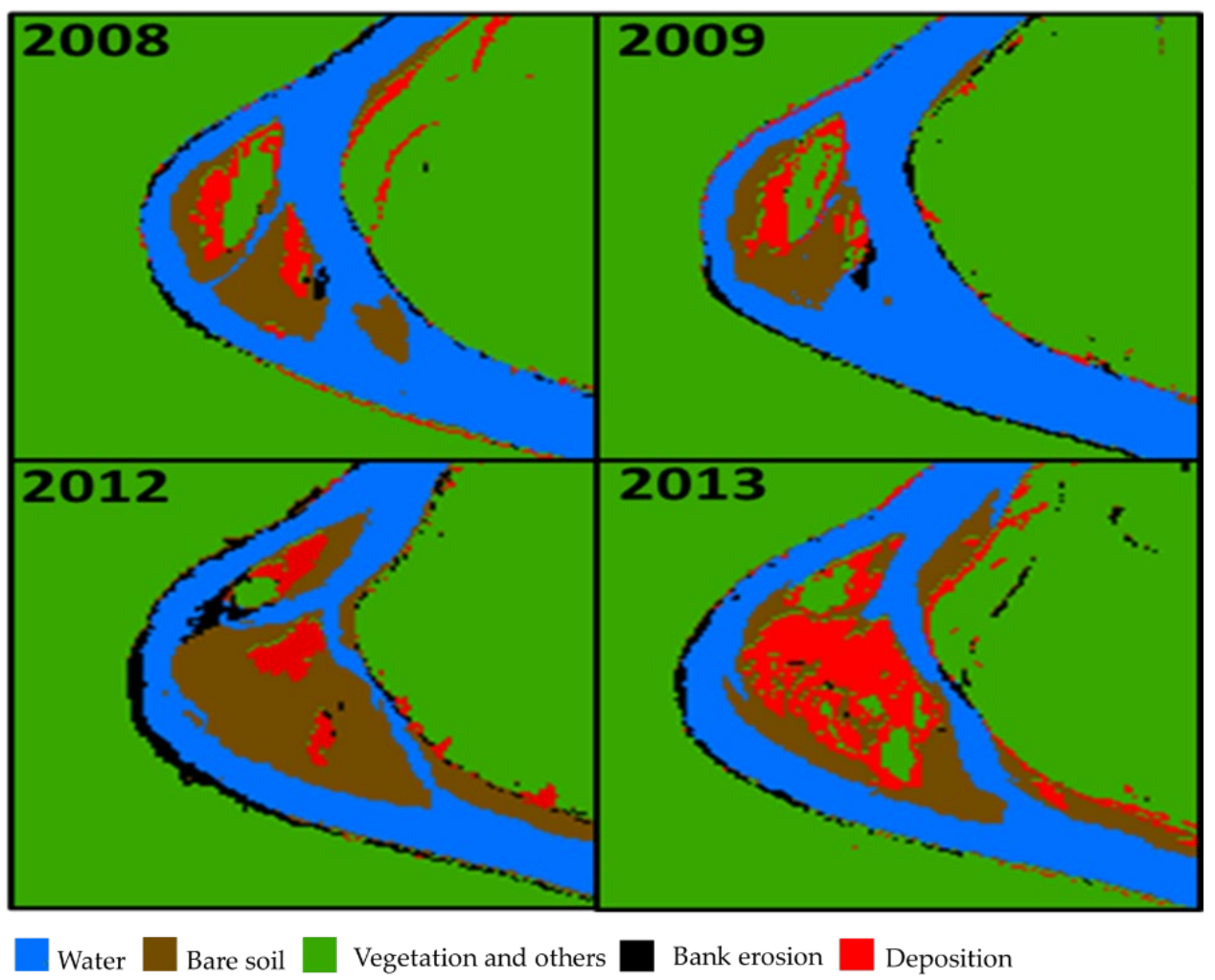

Figure 8. Main channel of the Muyuy anabranching during 2008, 2009, 2012, and 2013. More bank erosion was found in the 2012 severe flood; subsequently, a large deposition (bare soil) formed an island in 2013.

Table 4 shows the bank erosion and deposition in the Muyuy anabranching of the four analyzed years. The bank erosion and deposition calculation is explained in Section 4.5 and illustrated in Figure 6. The bank erosion areas in 2008, 2009, 2012, and 2013 were 1.76, 2.85, 5.11 , and $1.54 \mathrm{~km}^{2}$, respectively. As expected, the most significant bank erosion occurred in the 2012 severe flood, and the least amount of bank erosion occurred in 2013 after the 2012 flood. The area of the bank erosion that occurred in 2013 was only 30\% of that in 2012. The total deposition area from 2008, 2009, 2012, and 2013 amounted to 8.92, 5.64, 7.03, and $14.36 \mathrm{~km}^{2}$, respectively. Furthermore, the largest deposition rate with an area of $14.36 \mathrm{~km}^{2}$ can be found in 2013, after the 2012 flood. 
Table 4. Results distribution for bank erosion and deposition of the four-year analysis.

\begin{tabular}{cccc}
\hline & $\begin{array}{c}\text { Bank Erosion } \\
\mathbf{( k m}^{\mathbf{2}}\end{array}$ & $\begin{array}{c}\text { Deposition } \\
\mathbf{( k m}^{\mathbf{2}} \mathbf{)}\end{array}$ & $\begin{array}{c}\text { Annual Maximum } \\
\text { Water Level } \\
\mathbf{( m . a . s .} \mathbf{)})\end{array}$ \\
\hline 2008 & 1.76 & 8.92 & 116.80 \\
2009 & 2.85 & 5.64 & 117.73 \\
2012 & 5.11 & 7.03 & 118.97 \\
2013 & 1.54 & 14.36 & 117.99 \\
\hline
\end{tabular}

Note: the total area in the Muyuy anabranching region is $552.06 \mathrm{~km}^{2}$.

To highlight the influence of the water level, especially for the 2012 flood, on the erosion and deposition rates in the Muyuy anabranching structures, the histogram in Figure 9 shows the share of land cover areas in the total study area in correlation with the maximum water level in the individual years. Figure 9 clearly shows that the highest amount of erosion occurred in 2012 with the highest water level. However, the least amount of erosion occurred in 2013, although the lowest water level existed in 2008. In contrast, the share of deposition in 2013 was twice that in 2012. Although the erosion and deposition rates do not entirely correlate with the water levels, the results in Figure 9 show that as the water levels rise, the erosion rates increase and the deposition rates decrease. In addition, a large amount of deposition found in 2013 resulted from substantial sediment accumulated in the recession period of the 2012 flood.

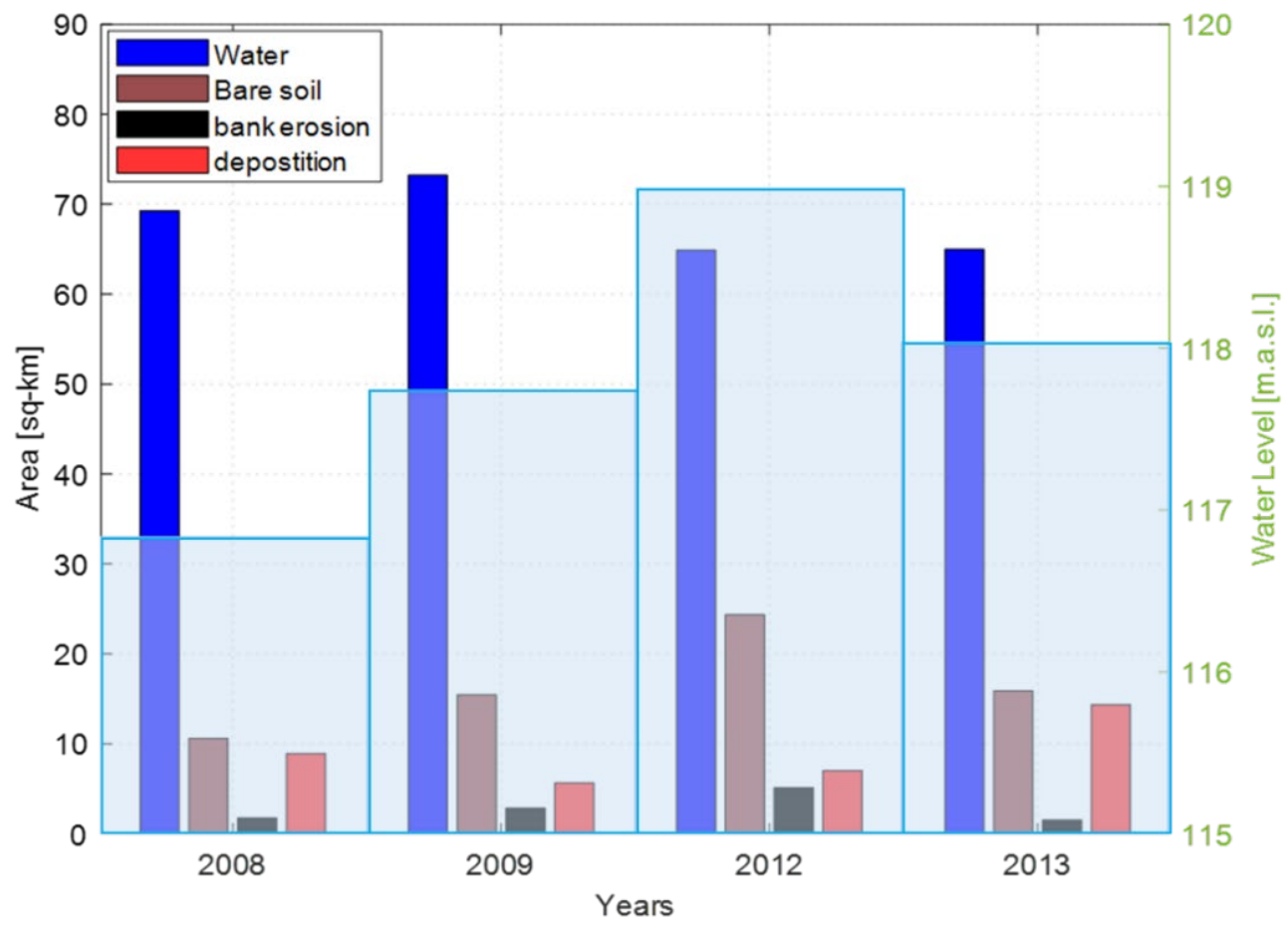

Figure 9. Bank erosion and deposition occurring in the studied years.

The historic flood in 2012, having a maximum water level of 118.97 m.a.s.l., produced a major area change of $36.5 \mathrm{~km}^{2}$ between the wet and dry seasons, thus indicating an exceptionally dynamic development of the anabranching system in this area. On the contrary, the lowest water level was in 2008, which corresponds to the slight change in the total area of $21.27 \mathrm{~km}^{2}$, indicating only small dynamic planform changes in the Muyuy system. Therefore, for the studied four years, the dynamic planform changes given as the change in total area directly correlated with the maximum annual water level measured at the Iquitos gauging station. The findings presented herein are in accordance with the 
results of Frias et al. [15], who reported that the planform changes of the main channel increased significantly due to the historical water level.

In this study, the satellite image selection was based on a cloud percentage of less than $20 \%$; hence, only limited images were used to analyze the seasonal change. This prevented the use of images from months with the highest peak discharges (from March to May), which is a limitation of this study.

\section{Conclusions}

The long-term evolution of the anabranching planform has been widely analyzed in previous studies associated with the Upper Peruvian Amazon River. This study focused on investigating the changes in the Muyuy anabranching planform and its structure due to the seasonal flow fluctuation and the 2012 severe flood. The planform changes were detected using the Landsat images based on the NDVI land cover classification. Images of the wet and dry seasons in 2008, 2009, 2012, and 2013 were collected. The land cover was classified into areas of water, bare soil, and vegetation and others in each image. The riparian erosion and deposition were determined by detecting the changes in land cover distribution between two successive images.

During the period between 2008 and 2013, the mean water level measured at the Iquitos station was $113.14 \mathrm{~m}$ a.s.l. Regarding the specific analysis, the mean water level was around $109.82 \mathrm{~m}$ in the dry season (September) and $116.44 \mathrm{~m}$ a.s.l. in the wet season (January to March). The peak water stage among the available records of the studied period (2008-2013) was $118.97 \mathrm{~m}$ a.s.l, which was caused by the 2012 flood. Such a water level variation resulted in prominent erosion/deposition in the anabranching planform. The area of Muyuy anabranching analyzed in this study is $552.06 \mathrm{~km}^{2}$. The result showed that, due to the water level variation, the mean area covered by water varied from $15.6 \%$ in the wet season to $12.2 \%$ in the dry season; the area covered by bare soil was $1.1 \%$ in the wet season and $3.3 \%$ in the dry season. It can be inferred that intensive erosion occurred due to the 2012 flood, based on the detection of an area of $5.15 \mathrm{~km}^{2}$ covered by bare soil, and the amount of erosion caused by this flood was twice the amount calculated in 2008, 2009, and 2013. Moreover, a substantial deposition of $14.36 \mathrm{~km}^{2}$ was observed in 2013 after the 2012 severe flood.

In this study, the planform changes were detected using remote sensing images. The change in the occupied area of a certain land cover class was used to roughly measure the degree of erosion/deposition. It should be noted that the limitation of the present study is the inability to assess the volume of erosion or deposition in detail. Improvement can be conducted in future studies by integrating the results of image analysis with channel crosssection data, so the erosion/deposition volume can be adequately estimated. In addition, high-resolution remote sensing images, such as SPOT or KOMPSAT, would be superior choices for undertaken erosion/deposition evaluations.

Author Contributions: Conceptualization, methodology, K.G.A. and K.T.L.; software, validation, formal analysis, writing-original draft preparation, K.G.A.; supervision, K.T.L. All authors have read and agreed to the published version of the manuscript.

Funding: This research received no external funding.

Data Availability Statement: Data supporting reported results can be asked to the first author.

Acknowledgments: The first author would like to thank the officers and technical personnel from the Service of Hydrography and Navigation of the Amazon (SHNA), Peruvian Navy, especially Jorge Paredes, Victor Vivanco, Renzo Whittembury, and Luis Gutiérrez for all the unconditional support. The Peruvian Navy owns the data used in this manuscript. Anyone interested in obtaining the data should contact the Service of Hydrography and Navigation of the Amazon (SHNA) at sehinav@shna.mil.pe.

Conflicts of Interest: The authors declare no conflict of interest. 


\section{References}

1. Dunne, T.; Aalto, R.E. Large river floodplains. In Treatise on Geomorphology; Academic Press: Cambridge, MA, USA, 2013; Volume 9, pp. 645-678.

2. Wohl, E. Hydrology and Discharge. In Large Rivers: Geomorphology and Management; Gupta, A., Ed.; John Wiley \& Sons: Chichester, UK, 2007; pp. 29-41.

3. Wynn, T.; Mostaghimi, S. The effects of vegetation and soil type on streambank erosion. Southwestern Virginia, USA. J. Am. Water Resour. Assoc. 2006, 42, 69-82. [CrossRef]

4. Chatterjee, S.; Krishna, A.P. Geospatial assessment of soil erosion vulnerability at a watershed level in some sections of the Upper Subarnarekha river basin, Jharkhand, India. Environ. Earth Sci. 2014, 71, 357e374. [CrossRef]

5. Daly, E.R.; Miller, R.B.; Fox, G.A. Modeling streambank erosion and failure along protected and unprotected composite streambanks. Adv. Water Resour. 2015, 81, 114-127. [CrossRef]

6. Botero-Acosta, A.; Chua, M.L.; Guzman, J.A.; Starks, P.J.; Moriasi, D.N. Riparian erosion vulnerability model based on environmental features. J. Environ. Manag. 2017, 203, 592-602. [CrossRef] [PubMed]

7. Sale, J.; Kalliola, R.; Hakkinen, I.; Makinen, Y.; Niemala, P.; Puhakka, M.; Coley, P.D. River dynamics and the diversity of Amazon lowland forest. Nature 1986, 322, 254-258. [CrossRef]

8. Yang, X.; Damen, C.J.M.; Zuidam, A.R. Satellite remote sensing and GIS for the analysis of channel migration changes in the active Yellow River Delta, China. Int. J. Appl. Earth Obs. Geoinf. 1999, 1, 146-157. [CrossRef]

9. Kummu, M.; Lu, X.X.; Rasphone, A.; Juha, S.; Jorma, K. Riverbank changes along the Mekong River: Remote sensing detection in the Vientiane-Nong Khai area. Quat. Int. 2008, 186, 100-112. [CrossRef]

10. Hassan, M.S.; Mahmud-ul-islam, S. Quantification of River Bank Erosion and Bar Deposition in Chowhali Upazila, Sirajganj District of Bangladesh: A Remote Sensing Study. J. Geosci. Environ. Prot. 2016, 4, 50-57. [CrossRef]

11. Jeong, Y.; Lee, K.J.; Chae, T.B.; Yu, J. Analysis of Tidal Channel Variations Using High Spatial Resolution Multispectral Satellite Image in Sihwa Reclaimed Land, South Korea. Korean J. Remote Sens. 2020, 36, 1605-1613.

12. Kalliola, R.; Salo, J.; Puhakka, M.; Rajasilta, M.; Häme, T.; Neller, R.; Räsänen, M.; Danjoy, A.W. Upper Amazon channel migration. Implication for vegetation perturbance and succession using bitemporal Landsat MSS images. Naturwissenschaffen 1992, 79, 76-79.

13. Rozo, M.G.; Nogueira, A.C.R.; Truckenbrodt, W. The anastomosing pattern and the extensively distributed scroll bars in the middle Amazon River. Earth Surf. Processes Landf. 2012, 37, 1471-1488. [CrossRef]

14. Rozo, M.G.; Nogueira, A.C.R.; Castro, C.S. Remote sensing-based analysis of the planform changes in the Upper Amazon River over the period 1986-2006. J. S. Am. Earth Sci. 2014, 51, 28-44. [CrossRef]

15. Frias, C.E.; Abad, J.D.; Mendoza, A.; Paredes, J.; Ortals, C.; Montoro, H. Planform evolution of two anabranching structures in the Upper Peruvian Amazon River. Water Resour. Res. 2015, 51, 2742-2759. [CrossRef]

16. Mendoza, A.; Abad, J.D.; Frias, C.E.; Ortals, C.; Paredes, J.; Montoro, H.; Soto-Cortés, G. Planform dynamics of the Iquitos anabranching structure in the Peruvian Upper Amazon River. Earth Surf. Processes Landf. 2016, 41, 961-970. [CrossRef]

17. Yen, C.L.; Lee, K.T. Bed topography and sediment sorting in channel bend with unsteady flow. J. Hydraul. Eng. ASCE 1995, 121, 591-599. [CrossRef]

18. Lee, K.T.; Liu, Y.L.; Cheng, K.H. Experimental investigation of bed load transport processes under unsteady flow conditions. Hydrol. Process. 2004, 18, 2439-2454. [CrossRef]

19. Puhakka, M.; Kalliola, R.; Rajasilta, M.; Salo, J. River Types, Site Evolution and Successional Vegetation Patterns in Peruvian Amazonia. J. Biogeogr. 1992, 19, 651. [CrossRef]

20. Guan, M.; Wright, N.G.; Sleigh, P.A. Multiple effects of sediment transport and geomorphic processes within flood events: Modelling and understanding. Int. J. Sediment Res. 2015, 30, 371-381. [CrossRef]

21. Karimaee Tabarestani, M.; Zarrati, A.R. Sediment transport during flood event: A review. Int. J. Environ. Sci. Technol. 2015, 12, 775-788. [CrossRef]

22. Abad, J.D.; Frias, C.E.; Buscaglia, G.C.; Garcia, M.H. Modulation of the flow structure by progressive bedforms in the Kinoshita meandering channel. Earth Surf. Processes Landf. 2013, 38, 1612-1622. [CrossRef]

23. Abad, J.D.; Paredes, J.; Montoro, H. Similarities and differences between a large meandering river and an ana-branching river: The Ucayali and Amazon River cases. In Proceedings of the 2010 Fall Meeting, AGU, San Francisco, CA, USA, 13-17 December 2010. EP24B-04.

24. Abad, J.; Vizcarra, J.; Paredes, J.; Montoro, H. Morphodynamics of the upper Peruvian Amazonian rivers, implications into fluvial transportation. In Proceedings of the IDS 2013-First International Conference, Iquitos, Peru, 17-19 July 2013; pp. 1-10.

25. Abad, J.D.; Garcia, M.H. Experiments in a high-amplitude Kinoshita meandering channel. 1: Implications of bend orientation on mean and turbulent flow structure. Water Resour. Res. 2009, 45, W02401. [CrossRef]

26. Abad, J.D.; Garcia, M.H. Experiments in a high-amplitude Kinoshita meandering channel. 2: Implications of bend orientation on bed morphodynamics. Water Resour. Res. 2009, 45, W02402. [CrossRef]

27. Mertes, L.A.; Dunne, T.; Martinelli, L.A. Channel-floodplain geomorphology along the Solimoes-Amazon River, Brazil. GSA Bull. 1996, 108, 1089-1107. [CrossRef]

28. Arce-Nazario, J. Landscape Javier A. Images in Amazonian Narrative: The Role of Oral History in Environmental Research. Conserv. Soc. 2007, 5, 115-133. 
29. Armijos, E.; Crave, A.; Vauchel, P.; Fraizy, P.; Santini, W.; Moquet, J.-S.; Guyot, J.-L. Suspended sediment dynamics in the Amazon River of Peru. J. S. Am. Earth Sci. 2013, 44, 75-84. [CrossRef]

30. Pinedo-Vasquez, M.; Barletti Pasqualle, J.; Del Castillo Torres, D.; Coffey, K. A tradition of change: The dynamic relationship between biodiversity and society in sector Muyuy, Peru. Environ. Sci. Policy 2002, 5, 43-53. [CrossRef]

31. Rebata, L.A.; Gingras, M.K.; Räsänen, M.E.; Barberi, M. Tidal-channel deposits on a delta plain from the Upper Miocene Nauta Formation, Maranon Foreland Sub-basin, Peru. Sedimentology 2006, 53, 971-1013. [CrossRef]

32. Räsänen, M.; Linna, A.; Irion, G.; Rebata, L.; Vargas, R.; Wesselingh, F.; Geología, Y. Geoformas de la zona de Iquitos. In Geoecología y Desarrollo Amazónico: Estudio Integrado en la Zona de Iquitos, Perú; Kalliola, R., Flores Paitán, S., Eds.; University of Turku: Turku, Finland, 1998; Volume 114, pp. 59-137.

33. Siiro, P.; Räsänen, M.; Gingras, M.; Harris, C.; Irion, G.; Pemberton, S.G.; Ranzi, A. Application of laser diffraction grain-size analysis to reveal depositional processes in tidally-influenced systems. In Fluvial Sedimentology VII, IAS Special Publication; Blum, M., Marriott, S., Leclair, S., Eds.; Blackwell Publishing: Oxford, UK, 2005; Volume 35, pp. 159-180.

34. Marengo, J.A.; Espinoza, J.C. Extreme seasonal droughts and floods in Amazonia: Causes, trends and impacts. Int. J. Climatol. 2015, 36, 1033-1050. [CrossRef]

35. Zhang, R.; Tang, X.; You, S.; Duan, K.; Xiang, H.; Luo, H. A novel feature-level fusion framework using optical and SAR remote sensing images for land use/land cover (LULC) classification in cloudy mountainous area. Appl. Sci. 2020, 10, 2928. [CrossRef]

36. Ling, J.; Zhang, H.; Lin, Y. Improving Urban Land Cover Classification in Cloud-Prone Areas with Polarimetric SAR Images. Remote Sens. 2021, 13, 4708. [CrossRef]

37. Chavez, P.S., Jr. Image-based atmospheric corrections-Revisited and improved. Photogramm. Eng. Remote Sens. 1996, 62, 1025-1036.

38. Milanović, M.M.; Micić, T.; Lukić, T.; Nenadović, S.S.; Basarin, B.; Filipović, D.J.; Tomić, M.; Samardžić, I.; Srdić, Z.; Nikolić, G.; et al. Application of Landsat-derived NDVI in monitoring and assessment of vegetation cover changes in Central Serbia. Carpathian J. Earth Environ. Sci. 2019, 14, 119-129. [CrossRef]

39. Groeneveld, D.P.; Baugh, W.M. Correcting satellite data to detect vegetation signal for eco-hydrologic analyses. J. Hydrol. 2007, 344, 135-145. [CrossRef]

40. Jensen, J.R. Introductory Digital Image Processing: A Remote Sensing Perspective, 3rd ed.; Prentice-Hall: Upper Saddle River, NJ, USA, 2005; pp. 505-512.

41. Yüksel, A.; Akay, A.; Gundogan, R. Using ASTER Imagery in Land Use/cover Classification of Eastern Mediterranean Landscapes According to CORINE Land Cover Project. Sensors 2008, 8, 1237-1251. [CrossRef]

42. Wu, Y.; Li, W.; Wang, Q.; Yan, S. Landslide susceptibility assessment using frequency ratio, statistical index and certainty factor models for the Gangu County, China. Arab. J. Geosci. 2016, 9, 84. [CrossRef]

43. Gyssels, G.; Poesen, J.; Bochet, E.; Li, Y. Impact of plant roots on the resistance of soils to erosion by water: A review. Prog. Phys. Geogr. 2005, 29, 189-217. [CrossRef]

44. De Baets, S.; Poesen, J.; Knapen, A.; Barberá, G.G.; Navarro, J.A. Root characteristics of representative Mediterranean plant species and their erosion-reducing potential during concentrated runoff. Plant Soil 2007, 294, 169-183. [CrossRef]

45. Li, X.-L.; Marschner, H.; George, E. Acquisition of phosphorus and copper by VA-mycorrhizal hyphae and root to shoot transport in white clover. Plant Soil 1991, 136, 49-57. [CrossRef]

46. Zhou, Z.C.; Shangguan, Z.P. Soil anti-scouribility enhanced by plant roots. J. Integr. Plant Biol. 2005, 47, 676-682. [CrossRef]

47. De Baets, K.; Klug, C.; Korn, D. Anetoceratinae (Ammonoidea, Early Devonian) from the Eifel and Harz Mountains (Germany) with a revision of their genera. Neues Jahrb. Für Geol. Paläontologie Abh. 2009, 252, 361-376. [CrossRef]

48. Vannoppen, W.; Vanmaercke, M.; DeBaets, S.; Poesen, J. A review of the mechanical effects of plant roots on concentrated flow erosion rates. Earth Sci. Rev. 2015, 150, 666-678. [CrossRef]

49. Gross, D. Monitoring Agricultural Biomass Using NDVI Time Series; Food and Agriculture Organization of the United Nations (FAO): Rome, Italy, 2005.

50. Montandon, L.; Small, E. The impact of soil reflectance on the quantification of the green vegetation fraction from NDVI. Remote Sens. Environ. 2008, 112, 1835-1845. [CrossRef]

51. Ortega-Martin, P.; García-Montero, L.G.; Sibelet, N. Temporal Patterns in Illumination Conditions and Its Effect on Vegetation Indices Using Landsat on Google Earth Engine. Remote Sens. 2020, 12, 211. [CrossRef]

52. Wang, Y.; Colby, J.D.; Mulcahy, K.A. An efficient method for mapping flood extent in a coastal flood plain using Landsat TM and DEM data. Int. J. Remote Sens. 2002, 23, 3681-3696. [CrossRef]

53. Sanyal, J.; Lu, X.X. Application of Remote Sensing in Flood Management with Special Reference to Monsoon Asia: A Review. Nat. Hazards 2004, 33, 283-301. [CrossRef]

54. Al-Doski, J.; Shattri, B.; Zulhaidi, M. NDVI Differencing and Post-classification to Detect Vegetation Changes in Halabja City, Iraq. IOSR J. Appl. Geol. Geophys. 2013, 1, 1-10. [CrossRef]

55. Sharma, N.; Akhtar, M.P.; Zeleke, B. Satellite Data Based Impact Assessment of Basin Characteristics for Brahmaputra River System of India. In Proceedings of the World Environmental and Water Resources Congress, Palm Springs, CA, USA, 22-26 May 2011.

56. Aalto, R.; Lauer, J.W.; Dietrich, W.E. Spatial and temporal dynamics of sediment accumulation and exchange along Strickland River floodplains (Papua New Guinea) over decadal-to-centennial timescales. J. Geophys. Res. 2008, 113, F01S04. [CrossRef] 
57. Fisher, G.B.; Bookhagen, B.; Amos, C.B. Channel planform geometry and slopes from freely available high-spatial resolution imagery and DEM fusion: Implications for channel width scalings, erosion proxies, and fluvial signatures in tectonically active landscapes. Geomorphology 2013, 194, 46-56. [CrossRef]

58. Gurnell, A. Adjustments in river channel geometry associated with hydraulic discontinuities across the fluvial-tidal transition of a regulated river. Earth Surf. Process. Landform. 1997, 22, 967-985. [CrossRef]

59. Gurnell, A.M. Channel change on the River Dee meanders, 1946-1992, from the analysis of air photographs. Regul. Rivers Res. Manag. 1997, 13, 13-26. [CrossRef]

60. Lauer, J.W.; Parker, G. Net local removal of floodplain sediment by river meander migration. Geomorphology 2008, 96, 123-149. [CrossRef]

61. Mount, N.; Louis, J. Estimation and propagation of error in measurements of river channel movement from aerial imagery. Earth Surf. Process. Landform. 2005, 30, 635-643. [CrossRef]

62. Peixoto, J.M.A.; Nelson, B.W.; Wittmann, F. Spatial and temporal dynamics of river channel migration and vegetation in central Amazonian white-water floodplains by remote-sensing techniques. Remote Sens. Environ. 2009, 113, 2258-2266. [CrossRef]

63. Richard, G.A.; Julien, P.Y.; Baird, D.C. Statistical analysis of lateral migration of the Rio Grande, New Mexico. Geomorphology 2005, 71, 139-155. [CrossRef]

64. Winterbottom, S.J.; Gilvear, D.J. A GIS-based approach to mapping probabilities of river bank erosion: Regulated River Tummel, Scotland. Regul. Rivers Res. Manag. 2000, 16, 127-140. [CrossRef]

65. Gurnell, A.M.; Downward, S.R.; Jones, R. Channel planform change on the River Dee meanders, 1876-1992. Regul. Rivers Res. Manag. 1994, 9, 187-204. [CrossRef]

66. Brumby, S.P.; Theiler, J.; Perkins, S.J.; Harvey, N.J.; Szymanski, J.J.; Bloch, J.J.; Mitchell, M. Investigation of image feature extraction by a genetic algorithm. In Proceedings of the SPIE's International Symposium on Optical Science, Engineering, and Instrumentation, Applications and Science of Neural Networks, Fuzzy Systems, and Evolutionary Computation II. International Society for Optics and Photonics, Denver, CO, USA, 18 July 1999; Volume 3812, pp. 24-31. [CrossRef]

67. Dey, A.; Bhattacharya, R.K. Monitoring of river center line and width-A study on river Brahmaputra. J. Indian Soc. Remote Sens. 2014, 42, 475-482. [CrossRef]

68. Dillabaugh, C.R.; Niemann, K.O.; Richardson, D.E. Semi-automated extraction of rivers from digital imagery. GeoInformatica 2002, 6, 263-284. [CrossRef]

69. Hamilton, S.K.; Kellndorfer, J.; Lehner, B.; Tobler, M. Remote sensing of floodplain geomorphology as a surrogate for biodiversity in a tropical river system (Madre de Dios, Peru). Geomorphology 2007, 89, 23-38. [CrossRef]

70. Marra, W.A.; Kleinhans, M.G.; Addink, E.A. Network concepts to describe channel importance and change in multichannel systems: Test results for the Jamuna River, Bangladesh. Earth Surf. Process. Landf. 2014, 39, 766-778. [CrossRef]

71. McFeeters, S. The use of the Normalized DifferenceWater Index (NDWI) in the delineation of open water features. Int. J. Remote Sens. 1996, 17, 1425-1432. [CrossRef]

72. Merwade, V.M. An automated GIS procedure for delineating river and lake boundaries. Trans. GIS 2007, 11, 213-231. [CrossRef]

73. Quackenbush, L.J. A review of techniques for extracting linear features from imagery. Photogramm. Eng. Remote Sens. 2004, 70, 1383-1392. [CrossRef]

74. Smith, L.C.; Pavelsky, T.M. Estimation of river discharge, propagation speed, and hydraulic geometry from space: Lena River, Siberia. Water Resour. Res. 2008, 44, W03427. [CrossRef]

75. Xu, H. Modification of normalized difference water index (NDWI) to enhance open water features in remotely sensed imagery Int. J. Remote Sens. 2006, 27, 3025-3033. [CrossRef]

76. Zolezzi, G.; Luchi, R.; Tubino, M. Modeling morphodynamic processes in meandering rivers with spatial width variations. Rev. Geophys. 2012, 50, RG4005. [CrossRef]

77. Rowland, J.C.; Shelef, E.; Pope, P.A.; Muss, J.; Gangodagamage, C.; Brumby, S.P.; Wilson, C.J. A morphology independent methodology for quantifying planview river change and characteristics from remotely sensed imagery. Remote Sens. Environ. 2016, 184, 212-228. [CrossRef]

78. Downward, S.; Gurnell, A.; Brookes, A. A methodology for quantifying river channel planform change using GIS. IAHS PublicationsSeries of Proceedings and Reports; International Association of Hydrological Sciences: Wallingford, Oxfordshire, UK, 1994; Volume 224, pp. 449-456. 